\title{
New species and new records of Laboulbeniales (Ascomycota) from Thailand
}

\section{Rossi W and Bernardi M}

Sect. Environmental Sciences, Dept. MeSVA, University of L'Aquila, 67100 Coppito (AQ), Italy

Rossi W, Bernardi M 2018 - New species and new records of Laboulbeniales (Ascomycota) from Thailand. Mycosphere 9(6), 1151-1172, Doi 10.5943/mycosphere/9/6/6

\begin{abstract}
Eight new species of Laboulbeniales (Ascomycota) are described. These are Corethromyces fuscoramosus, parasitic on Medon sp. (Coleoptera, Staphylinidae); Eucantharomyces ferreroi, parasitic on Pogonoglossus sp. (Coleoptera, Carabidae); Euphoriomyces rugosus, parasitic on Agathidium sp. (Coleoptera, Leiodidae); Kyphomyces siamensis, parasitic on Holotrochus sp. (Staphylinidae); Rickia cifoneae, parasitic on Melisia spp. (Acarina, Canestriniidae); Stigmatomyces coronatus, parasitic on Ochthera sp. (Diptera, Ephydridae); Teratomyces cylindrocarpus, parasitic on Diochus sp. (Staphylinidae); Zeugandromyces assingii, parasitic on Neosclerus areolatus (Staphylinidae). Twenty-nine species are reported for the first time from Thailand, 5 of which are new for the whole Asian continent and 8 are recorded for the first time after description. A new synonymy is established: Stigmatomyces subcircinalis Thaxt. $1931=S$. tortilis Thaxt. 1918.
\end{abstract}

Key words -8 new species - Ectoparasitic fungi - Indochina - Mites - Laboulbeniomycetes Taxonomy

\section{Introduction}

The first records of Laboulbeniales from Thailand are more than one hundred years old. These are two species of Laboulbenia (L. orectochili Thaxt. and L. proliferans Thaxt.) reported by Roland Thaxter in the second part of his huge monograph, in 1908. A third species was added only after 72 years, i.e. Arthrorhynchus eucampsipodae Thaxt. (Blackwell 1980). Other 30 species were reported and illustrated a few years later in a large paper by Sugiyama \& Panichapol (1984). Actually, the new records were 28 because one of the latter species, Laboulbenia proliferans, was already reported by Thaxter and another, Chitonomyces chungii Thaxt., was later considered a synonym of $C$. backeri Thaxt. (Santamaria 2001). Moreover, in this same paper a few species were misidentified and later corrected: Chitonomyces manubriolatus Thaxt. to C. spinosus Thaxt. (Santamaria 2001), Laboulbenia tachyis Thaxt. to L. egens Speg. (Santamaria et al. 1991), and Zodiomyces subseriatus Thaxt. to Z. vorticellarius Thaxt. (Santamaria 2004). Another correction is needed: the parasites on Morion sp. were identified as Laboulbenia morionis Thaxt., but Fig. 7E clearly illustrates another species, likely related to L. papuana Thaxt.

After the paper by Sugiyama and Panichapol the number of Laboulbeniales from Thailand increased by five species: Laboulbenia gratiellae W. Rossi (Rossi 1987); Stigmatomyces rugosus Thaxt. (Rossi 1988); Laboulbenia clivinalis Thaxt. (Santamaria et al. 1991); Botryandromyces heteroceri (Maire) I. I. Tav. et T. Majewski (Santamaria \& Rossi 1999); Stigmatomyces 
limnophorae Thaxt. (Rossi et al. 2013). Therefore, to date the total number of recorded species is 36 (Table 1).

In the present paper eight new species are described and other 29 are reported for the first time from Thailand, 5 of which are new for the whole Asian continent. The numerous new findings, which redouble the number of Siamese Laboulbeniales, made it possible to better define the geographical distribution and the taxonomic position of several species. A new synonymy is also established: Stigmatomyces subcircinalis Thaxt. 1931 $=$ S. tortilis Thaxt. 1918 .

Table 1 Laboulbeniales recorded from Thailand before the present paper.

\begin{tabular}{|c|c|c|c|}
\hline Fungus species & Host family & Host insect & Bibliography \\
\hline Arthrorhynchus eucampsipodae Thaxt. & Nycteribiidae & Eucampsipoda inermis Theodor & Blackwell 1980 \\
\hline Autoicomyces falcifer (Thaxt.) Thaxt. & Hydrophilidae & Regimbartia attenuata (Fabricius) & Sugiyama \& Phanichapol 1984 \\
\hline Autoicomyces helocharalis Thaxt. & Hydrophilidae & Helochares lentus Sharp & Sugiyama \& Phanichapol 1984 \\
\hline Autoicomyces siamensis K. Sugiyama et Phanich. & Hydrophilidae & Regimbartia attenuata (Fabricius) & Sugiyama \& Phanichapol 1984 \\
\hline Botryandromyces heteroceri (Maire) I.I.Tav. et T. Majewski & Hetroceridae & Augyles gabriellae (Mascagni) & Santamaria \& Rossi 1999 \\
\hline $\begin{array}{l}\text { Chitonomyces bakeri Thaxt. } \\
=C \text {. chungii Thaxt. }\end{array}$ & Dytiscidae & $\begin{array}{l}\text { Laccophilus parvulus obtusus } \\
\text { Sharp }\end{array}$ & $\begin{array}{l}\text { Sugiyama \& Phanichapol 1984, } \\
\text { Santamaria } 2001\end{array}$ \\
\hline Chitonomyces chinensis Thaxt. & Dytiscidae & Laccophilus spp. & Sugiyama \& Phanichapol 1984 \\
\hline Chitonomyces japanensis Thaxt. & Dytiscidae & Laccophilus siamensis Sharp & Sugiyama \& Phanichapol 1984 \\
\hline Chitonomyces javanicus Thaxt. & Dytiscidae & Laccophilus spp. & Sugiyama \& Phanichapol 1984 \\
\hline Chitonomyces ordinatus Thaxt. & Dytiscidae & Laccophilus spp. & Sugiyama \& Phanichapol 1984 \\
\hline Chitonomyces paradoxus (Peyritsch) Thaxt. & Dytiscidae & Laccophilus spp. & Sugiyama \& Phanichapol 1984 \\
\hline Chitonomyces rugosus Thaxt. & Dytiscidae & Copelatus tenebrosus Régimbart & Sugiyama \& Phanichapol 1984 \\
\hline $\begin{array}{l}\text { Chitonomyces spinosus Thaxt. } \\
\text { (sub C. manubriolatus Thaxt.) }\end{array}$ & Dytiscidae & Laccophilus spp. & $\begin{array}{l}\text { Sugiyama \& Phanichapol } 1984 \\
\text { Santamaria } 2001\end{array}$ \\
\hline Chitonomyces thaxteri Speg. & Dytiscidae & $\begin{array}{l}\text { Laccophilus parvulus obtusus } \\
\text { Sharp }\end{array}$ & Sugiyama \& Phanichapol 1984 \\
\hline Chitonomyces zonatus Thaxt. & Dytiscidae & $\begin{array}{l}\text { Laccophilus parvulus obtusus } \\
\text { Sharp }\end{array}$ & Sugiyama \& Phanichapol 1984 \\
\hline Dimeromyces cherrhonesites Balazuc & Tenebrionidae & Ceropria sp. & Sugiyama \& Phanichapol 1984 \\
\hline Dimeromyces oscinomalis Thaxt. & Chloropidae & gen. sp. & Sugiyama \& Phanichapol 1984 \\
\hline Enarthromyces indicus Thaxt. & Carabidae & Pheropsophus siamensis Chaudoir & Sugiyama \& Phanichapol 1984 \\
\hline Laboulbenia anoplogenii Thaxt. & Carabidae & $\begin{array}{l}\text { Egadroma quinquepustulatus } \\
\text { Wiedeman }\end{array}$ & Sugiyama \& Phanichapol 1984 \\
\hline Laboulbenia catascopi Thaxt. & Carabidae & Catascopus fuscoaeneus Chaudoir & Sugiyama \& Phanichapol 1984 \\
\hline Laboulbenia celestialis Thaxt. & Carabidae & Desera geniculata Klug & Sugiyama \& Phanichapol 1984 \\
\hline
\end{tabular}


Table 1 Continued.

\begin{tabular}{|c|c|c|c|}
\hline Fungus species & Host family & Host insect & Bibliography \\
\hline Laboulbenia clivinalis Thaxt. & Carabidae & $\begin{array}{l}\text { Clivina clivinoides Schmidt- } \\
\text { Goebel }\end{array}$ & Santamaria et al. 1991 \\
\hline $\begin{array}{l}\text { Laboulbenia egens Speg. } \\
\text { (sub L. tachyis Thaxt.) }\end{array}$ & Carabidae & $\begin{array}{l}\text { Tachys (Tachyura) poecilopserus } \\
\text { Bates }\end{array}$ & Sugiyama \& Phanichapol 1984 \\
\hline Laboulbenia gratiellae W. Rossi & Diopsidae & Cyrtodiopsis currani Shillito & Rossi 1987 \\
\hline Laboulbenia idiostoma Thaxt. & Chrysomelidae & Altica sp. & Sugiyama \& Phanichapol 1984 \\
\hline Laboulbenia kunckelii (Giard) Thaxt. & Carabidae & Mormolice phyllodes Hagenbach & Sugiyama \& Phanichapol 1984 \\
\hline Laboulbenia orectochili Thaxt. & Gyrinidae & $\begin{array}{l}\text { Orectochilus semivestitus Guérin- } \\
\text { Menev. }\end{array}$ & Thaxter 1908 \\
\hline $\begin{array}{l}\text { Laboulbenia sp. (near papuana Thaxt.) } \\
\text { (sub Laboulbenia morionis Thaxt.) }\end{array}$ & Carabidae & Morion sp. & Sugiyama \& Phanichapol 1984 \\
\hline Laboulbenia pheropsophi Thaxt. & Carabidae & Pheropsophus siamensis Chaudoir & Sugiyama \& Phanichapol 1984 \\
\hline Laboulbenia proliferans Thaxt. & Carabidae & $\begin{array}{l}\text { Craspedophorus sublaevis } \\
\text { (Chaudoir) } \\
\text { Chlaenius ducalis Chaudoir }\end{array}$ & $\begin{array}{l}\text { Thaxter } 1908 \\
\text { Sugiyama \& Phanichapol } 1984\end{array}$ \\
\hline Rhynchophoromyces denticulatus (Thaxt.) Thaxt. & Hydrophilidae & Helochares pallens (MacLeay) & Sugiyama \& Phanichapol 1984 \\
\hline Rhynchophoromyces rostratus (Thaxt.) Thaxt. & Hydrophilidae & $\begin{array}{l}\text { Enochrus spp. } \\
\text { Helochares pallens (MacLeay) }\end{array}$ & Sugiyama \& Phanichapol 1984 \\
\hline Rickia eumorphi Thaxt. & Endomychidae & Eumorphus spp. & Sugiyama \& Phanichapol 1984 \\
\hline Stigmatomyces limnophorae Thaxt. & Muscidae & Heliographa ceylanica Emden & Rossi et al. 2013 \\
\hline Stigmatomyces rugosus Thaxt. & Ephydridae & Psilopa sp. & Rossi 1988 \\
\hline $\begin{array}{l}\text { Zodiomyces vorticellarius Thaxt. } \\
\text { (sub Z. subseriatus Thaxt.) }\end{array}$ & Hydrophilidae & Helochares lentus Sharp & $\begin{array}{l}\text { Sugiyama \& Phanichapol } 1984 \\
\text { Santamaria } 2004\end{array}$ \\
\hline
\end{tabular}

\section{Materials \& Methods}

Most of the insects bearing Laboulbeniales were collected with the techniques usually utilized by entomologists (entomological net, sweeping net, aspirator, light trap) during three short journeys in Northern Thailand carried out by the authors (together or individually) in 2004,2016 and 2017. Collected insects were placed in $96 \%$ ethyl alcohol in the field (75\% in the journey of 2004) for transport to the laboratory, where they were carefully examined with a dissecting microscope. A few insects bearing Laboulbeniales reported in the present paper were obtained from museums or single entomologists. Fungi were removed from the hosts by means of an entomological pin (\#3) and permanent slides were prepared following the method described by Rossi \& Santamaria (2015). Holotypes are deposited in the Botanical Museum of Florence (FI); the other slides are temporarily 
preserved in the collection of the first author, which will be also deposited in the Botanical Museum of Florence. The host insects were sent for identification to the entomologists listed in the Acknowledgements and are preserved in their collections.

Photomicrographs were made with a Jenoptik ProgRes 10 Plus digital camera on a Leica DMR microscope equipped with differential interference contrast optics (DIC).

\section{Results}

\section{New species}

Corethromyces fuscoramosus W. Rossi \& Bernardi, sp. nov.

Fig. 1

MycoBank: MB828122

Etymology - From Latin fuscus (=dark), and ramosus (=branched).

Basal cell (cell I) hyaline, about as long as broad, with the dorsal margin usually convex. Suprabasal cell (cell II) very dark brown, distinctly shorter than the basal, irregularly pentagonal. Stalk-cell of the appendage (cell III) blackish brown except in its inner, upper angle, distinctly broader than long. Axis of the appendage blackish brown except the almost hyaline inner margin, the dark tinge continuous with that of cells II and III, bearing a dense tuft of branches almost reaching (rarely exceeding) the perithecial apex, most of which are thick, straight and dark brown, but the more internal ones (close to the perithecium) are slender, flexuous and hyaline. Stalk-cell of the perithecium (cell VI) rather stocky, gradually enlarging and fading from a dark, narrow base. Secondary stalk-cell (cell VII) and basal cells of the perithecium yellowish and subequal. Perithecium yellowish, broadly fusiform, tapering distally to a conical tip and a blunt apex. Length from foot to perithecial apex 155-195 $\mu \mathrm{m}$; perithecium (without basal cells) 95-105 $\times 25-30 \mu \mathrm{m}$; length from foot to tip of longest appendages $165 \mu \mathrm{m}$.

Material examined - THAILAND, Ciang Mai prov., Doi Suthep, nature trail Phalad, 29 Nov 2004, W. Rossi, on the distal portion of the abdomen of Medon sp. (Coleoptera, Staphylinidae), FI WR 3929, holotype. Seven mature and other 13 thalli at various stages of development have been observed.

Notes - The new species is clearly allied to Coretromyces medonis Thaxt., described on Medon spp. from Java and Borneo (Thaxter 1931). The most striking differences are in the shape, length, number and color of the branches of the appendages, which in $C$. medonis are slenderer, shorter, fewer and all hyaline. Moreover, in the latter species the suprabasal cell (cell II) is distinctly taller than the basal.

Eucantharomyces ferreroi W. Rossi \& Bernardi, sp. nov.

Fig. 2

MycoBank: MB828123

Etymology - Named after Franco Ferrero, for his invaluable help during our more recent stays in Thailand.

Thallus colored reddish orange, with darker basal cell of the antheridium and cell VII. Basal cell of the receptacle (cell I) distinctly longer and more slender than the suprabasal cell (cell II), overlapping the cuneate base of cell VI for almost half of its length. Basal cell of the appendage (cell III) broadly triangular, twice as long, or more, than maximum width, separated from cell II by a very oblique septum. Basal cell of the compound antheridium quadriangular, slightly wider than long, the marginal cell overlapping its upper half. Antheridial cells arranged in 7(8) oblique lines. Discharge tube long, slender, faintly sigmoid to almost straight. Terminal spine-like process (spore apex) conspicuous. Stalk cell of the perithecium (cell VI) relatively short, with the lower portion distinctly tapered and deeply inserted between the upper portions of cells I and III. Basal cells of the perithecium small. Perithecium elongate, longer than the rest of the thallus, slightly inflated near the base, gradually tapering without abrupt transition to a dome-shaped apex. Length from foot to perithecial apex 520-545 $\mu \mathrm{m}$; from foot to tip of discharge tube 260-270 $\mu \mathrm{m}$; perithecium 300$330 \times 70-75 \mu \mathrm{m}$. 
Material examined - THAILAND, Betong, April 1993, Strand, on the elytra of Pogonoglossus sp. (Coleoptera, Carabidae), FI WR1909, holotype. Ten mature and 9 immature thalli have been observed.

Notes - This new species is distinguished from all the other 29 described thus far in the same genus for cell VI deeply inserted between cells I and III. Moreover, only three previously described species have seven or more rows of antheridial cells inside the compound antheridium. These are Eucantharomyces basilewskii W. Rossi et Cesari, E. japonicus K. Sugiyama, and E. obae K. Sugiyama. Among the latter species, the first, parasitic on Zuphium spp. from Africa, is further distinguished by a stockier perithecium and a much shorter marginal cell of the antheridium (Rossi \& Cesari Rossi 1977). The second, parasitic on Planetes punctaticeps Andrews from Japan, by a stockier perithecium and longer marginal and basal cells of the antheridium (Sugiyama 1978b). The third, parasitic on Agonum sp. from Pakistan, was unfortunately described upon a single and, apparently, not fully mature thallus: however, it bears a longer marginal cell of the antheridium, a much shorter basal cell of the same, and a shorter cell III (Sugiyama 1981b).

Euphoriomyces rugosus W. Rossi \& Bernardi, sp. nov.

Figs 3,4 MycoBank: MB828124

Etymology - From Latin $=$ wrinkled, because of the wrinkled surface of the side of the thallus laying on the insect.

Thalli usually paired, with a hyaline perithecium and pale yellowish receptacle. Axis of the receptacle continuing with the primary appendage, the whole series consisting of 11-12 cells distinctly broader than long, except the basal, which is longer and slightly tapering to the foot. One or (rarely) two cells below the perithecium are divided by a vertical septum separating a sterile hemispherical cell. Perithecium single, originating laterally from the $4^{\text {th }}, 5^{\text {th }}$ or $6^{\text {th }}$ cell of the series on a short stalk curving upwards; perithecium body about four times longer than broad (with basal cells), asymmetrical, with the side facing the host-insect flattened, the opposite convex, tapering to a broadly conical tip bent upwards, ending in very unequal lips, the upper of which is much larger and bears a small tooth-like upgrowth. Length from foot to perithecial apex 100-112 $\mu \mathrm{m}$; longest branchlet of appendages $70 \mu \mathrm{m}$; perithecium 43-60 × 14-17 $\mu \mathrm{m}$.

Material examined - THAILAND, Ciang Rai prov., Wiang Pa Pao district, near Huay Nam Guen, about $1250 \mathrm{~m}, 1^{\circ} 07^{\prime} 40^{\prime} \mathrm{N}, 9^{\circ} 19^{\prime} 42^{\prime}$ E, 22-23 Feb 2017, M. Bernardi \& W. Rossi, on the elytra of a female specimen of Agathidium (A.) cf. newari Angelini \& De Marzo (Coleoptera, Leiodidae), FI WR4233a, holotype. Six mature and 12 thalli at various stages of development have been observed.

Notes - The thalli of the new species lay flat on the surface of the host-insect, with the perithecial tip pointing upwards, although it appears oriented laterally when compressed by the cover slip in the slide-mounts. The receptacle is very peculiar: the surface of the side in contact with the insect bears conspicuous, transverse, wavy wrinkles (Fig. 4), while the opposite side is smooth (Fig. 3). This characteristics, together with the shape of the perithecial tip, distinguish the new species from all the others in the same genus.

It is not unusual that Laboulbeniales lay flat on the host-insect with their thallus, but with the perithecial tip pointing upwards to facilitate the transmission of the sticky spores during contacts with other insects. For example, this was observed also in Dimeromyces perettiorum W. Rossi, Bernardi et J. A. Torres (Rossi et al. 2015). In the latter species the same result is obtained with the whole perithecium curving upwards, not only the tip, and there is no detectable difference between the two sides of the thallus.

Kyphomyces siamensis W. Rossi \& Bernardi, sp. nov.

Fig. 5

MycoBank: MB828125

Etymology - From Siam, the name of the country until 1949.

Thallus hyaline, except for the lower portion of the lower cell of the receptacle, which is brownish. Receptacle hardly reaching the base of the perithecium, consisting of (11)14-19 cells, of 
which the lower is broadly triangular, the others shorter than broad but rarely flattened, the subterminal subquadrate when not split into two cells, the uppermost elliptical, with the longer axis horizontal. Stalk cell of the perithecium irregularly quadrangular or pentagonal, about as long as broad or slightly shorter than broad. Perithecial basal cell conspicuous and persistent. Accessory cell hardly reaching one third of the length of the perithecium. The latter relatively small, with the venter slightly inflated, tapering without abrupt transition to a stocky neck and the hardly distinguished tip and apex. Length from foot to perithecial apex (140)220-290 $\mu \mathrm{m}$; perithecium $63-95 \times 10-12 \mu \mathrm{m}$.

Material examined - THAILAND, Ciang Rai prov., Wiang Pa Pao district, Huay Nam Guen, about $1250 \mathrm{~m}, 1^{\circ} 07^{\prime} 40^{\prime} \mathrm{N}, 9^{\circ} 19^{\prime} 42^{\prime \prime} \mathrm{E}, 26-28$ Oct 2016 , W. Rossi, on various ventral parts of Holotrochus sp. (Staphylinidae, Osoriinae), FI WR4196a, holotype.

Notes - The characteristic that distinguishes the new species from most of the others in the same genus is the shape of the perithecium: in Kyphomyces siamensis the latter has the distal portion rather stocky and not well distinguished from the basal portion. Among the previously described species, the only one bearing a perithecium with a similar shape is K. rhizophorus Thaxt., parasitic on Rugilus (sub Stilicus) ceylanensis (Kraatz) from Sumatra. The latter fungus, however, has a much shorter receptacle consisting of only 6-7 cells and it is also the only one in the genus Kyphomyces bearing at the base two elongate outgrowths likely working as buffer organs (Thaxter 1931). The absence of perithecial outgrowths and of a blackish outgrowth from the foot, the shape and number of cells forming the receptacle, and the axis hardly reaching the base of the perithecium further distinguish $K$. siamensis from the other species.

Rickia cifoneae W. Rossi \& Bernardi, sp. nov.

Fig. 6

MycoBank: MB828126

Thailand.

Etymology - Named after Prof. Maria Grazia Cifone for her support to our research in

Receptacle triseriate. Basal cell hyaline to light brown, distinctly longer than broad, extending upwards between the basal cells of the marginal series. Anterior series consisting of 7-10 (more frequently 8) hyaline and flattened cells, each bearing an appendiculate cell, ending at the base of the perithecium, with which its outer margin is continuous. Median series reaching the base of the perithecial tip, consisting of 16-20 cells, of which the lower 5-6 are larger and dark brown but not opaque, the others gradually smaller and paler, the 3-4 distal ones hyaline and appendiculate, extending beyond the posterior series. The latter composed of 18-20 hyaline and gradually smaller cells, each bearing an appendiculate cell. Bicellular base of the primary appendage conspicuous, oblong, with the lower cell almost entirely blackened and the upper hyaline, contrasting. Appendages rounded, subtended by a dark brown, cup-shaped base. Antheridia absent. Perithecium brown, with a blackish tip and translucent apex, its outer margin wholly free, while on the inner side the tip only is free; the latter is distinctly outcurved, forming and angle of about $90^{\circ}$ with the perithecial venter. Length from foot to the apex of the primary appendage 76-142 $\mu \mathrm{m}$; perithecium 63-54 × 24-25 $\mu \mathrm{m}$.

Material examined - THAILAND, Chiang Rai prov., Wiang Pa Pao district, Huay Nam Guen, about 1250 m, 1907'40”N, 99¹9'42”E, light trap, 26-28 Oct 2016, W. Rossi, on Melisia cf. superba Summers (Acarina, Canestriniidae) associated with Eupatorus gracilicornis Arrow (Scarabaeidae), FI WR4163, holotype; same data as the type, nos. 4162, 4164. INDONESIA, Java, 15 January 1933, local collector, on a few specimens of Melisia sp. found under the elytra of Aceraius grandis (Burmeister) (Passalidae) preserved in the Museo Civico di Zoologia in Rome (MCZR), slide VV297/WR; same data, VV411/WR; same data, 20 July 1933, VV396/WR.

Notes - The new species is related with Rickia berlesiana and R. elegans Thaxt., which however have the lower cells of the median series wholly opaque, the perithecial tip erect $(R$. berlesiana) or slightly bent outwards ( $R$. elegans), the appendages elongate, and the base of the primary appendage distinctly slenderer (Thaxter 1926). 

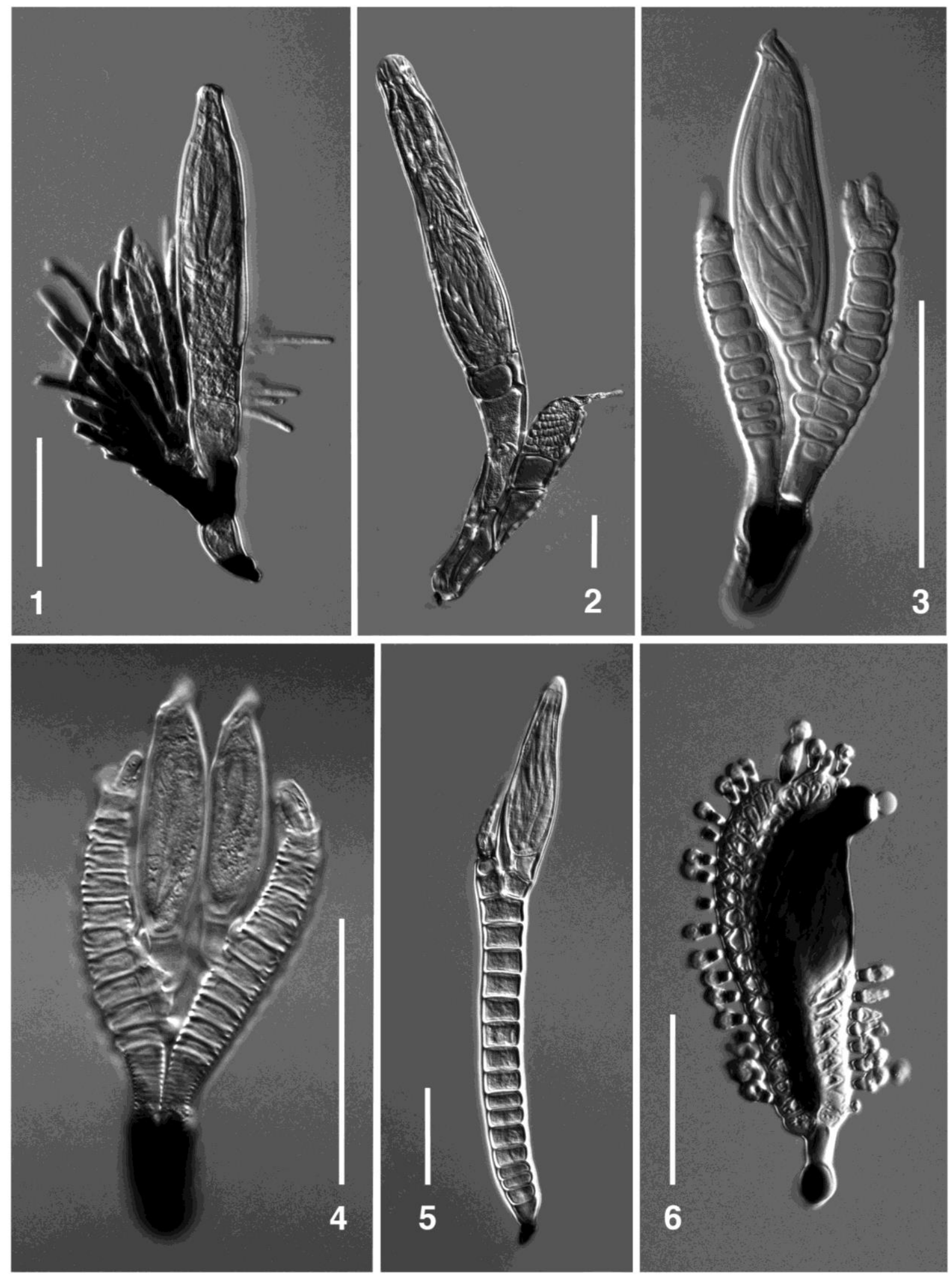

Figures 1-6 - 1 Coretromyces fuscoramosus. 2 Eucantharomyces ferreroi. 3,4 Euphoriomyces rugosus. 5 Kyphomyces siamensis. 6 Rickia cifoneae. Bars $=50 \mu \mathrm{m}$.

Stigmatomyces coronatus W. Rossi \& Bernardi, sp. nov.

Fig. 7

MycoBank: MB828127

Etymology - From Latin: crowned, because of the outgrowth forming a crown at the apex of the perithecium. 
Venter of perithecium and lower cell of the free appendage rusty red, quite dark in older specimens; the rest of the fungus is unequally colored with diluted reddish brown. Receptacle nearly isodiametric, with the suprabasal longer and distally slightly broader than the lower portion of the stalk-cells region. Stalk cell of the appendage rather short and stout. Axis of the free appendage consisting of five, gradually smaller cells, each bearing a pair of relatively large antheridia on the upper, inner angle, except the uppermost, which bears apically a third spinose antheridium, the spine being slender and straight. Stalk-cell of the perithecium small and subriangular; the two external cells above it distinctly prominent. Perithecial venter about twice as long as broad, slightly and symmetrically inflated, its surface granular to verruculose; the straight and elongate perithecial neck distinctly paler and slightly shorter than the venter, with a spreading base, rather abruptly inflated below the junction with the tip; the latter narrower, with nearly straight margins, abruptly tapered above; the apex consists of a "crown" of four elongate, subequal, symmetrically spreading outgrowths surrounding two small, very unequal projections, the longer of which is strongly curved. Total length $270-475 \mu \mathrm{m}$; perithecial venter $70-125 \times 35-70 \mu \mathrm{m}$; perithecial neck 75-115 $\mu \mathrm{m}$; free appendage 65-90 $\mu \mathrm{m}$; ascospores $43 \mu \mathrm{m}$.

Material examined - THAILAND, Chiang Mai prov., swamp at km 42 along the road no.118 to Chiang Rai, 27 Nov 2004, W. Rossi, on tergites of a female specimen of Ochthera sp. (Diptera, Ephydridae), FI WR3468, holotype. Twenty-seven mature and 19 immature thalli have been examined.

Notes - The very peculiar apex of perithecium makes Stigmatomyces coronatus distinguishable at first sight from any other known species in the same genus. As to the other parasites on flies of the genus Ochthera, the only one with a granulose surface of the perithecium is S. longimasculus W. Rossi \& Leonardi (2013), which is however different in almost any other morphological character. The new species might be allied to $S$. gracilis Thaxt., which has the free appendage with a similar structure and a conspicuous inflation at the junction of the perithecial neck with the tip, but the latter species, among other differences, lacks the apical outgrowths and the granulosity of the perithecium, and has the spine of the appendage much larger and distinctly curved (Thaxter 1908, plate XLVI, Figs 15-18).

Teratomyces cylindrocarpus W. Rossi \& Bernardi, sp. nov.

Fig. 8

MycoBank: MB828128

Etymology - For the almost cylindrical perithecium.

Receptacle translucent pale brown, consisting of three superimposed cells of about the same length but gradually enlarged from below upwards; on the basal cell is sometimes present a dark brown blotch. Appendiculate cells concolorous with the cells of the receptacle. Appendages spreading in a relatively small and loose tuft, each consisting of a dark brown, long, distally curved outwards basal cells bearing in a single row hyaline sterile branchlets, which are longer in the upper portion. Stalk cell of the perithecium almost hyaline, relatively short and stocky. Basal cells of the perithecium relatively large, concolorous and hardly distinguished from the perithecial body but separated from the stalk cell below by a distinct constriction. Perithecium single, tinged with pale reddish brown, subcylindrical, very long and slender, straight or faintly curved, the tip slightly narrower and slightly tapering to the blunt apex. Length from foot to perithecial apex 300-405 $\mu \mathrm{m}$; perithecium (without basal cells) 160-210 × 26-28 $\mu \mathrm{m}$; longest appendages $85 \mu \mathrm{m}$.

Material examined - THAILAND, Chiang Mai prov., Mae Lai river nr. Ban Pong Din, km 27,6 road no.118 to Chiang Rai, alt. 470 m, 27 Nov 2004, W. Rossi, at the apex of the abdomen of Diochus sp. (Coleoptera, Staphylinidae), FI WR3474, holotype. Seven mature and 12 immature or incomplete thalli have been observed.

Notes - The very elongate and almost cylindrical perithecium easily distinguishes the new species from the other ten described thus far in the same genus. Only Teratomyces mirificus Thaxt. and $T$. heterothopsis W. Rossi bear a vague resemblance with $T$. cylindrocarpus because of their slender habitus and the perithecial venter only slightly inflated. However, both these species have a 
much longer perithecial stalk, longer appendages, the receptacle distinctly tapering downwards and usually blackened (Rossi 2010, Bernardi et al. 2014).

Zeugandromyces assingii $\mathrm{W}$. Rossi \& Bernardi, sp. nov.

Fig. 9

MycoBank: MB828129

Etymology - Named after Volker Assing (Germany), distinguished entomologist and student of the Staphylinidae.

Thallus russet, with darker appendage and perithecial base and much paler cells I and VI. Basal cell of the receptacle (cell I) trapezoidal, tapering to the foot, about as long as maximum width. Suprabasal (cell II) broadly pentagonal, larger than cell I and slightly longer than broad. Stalk cell of the appendage (cell III) free for about half of its length, slightly smaller than cell II, from which is separated by an oblique septum. Appendage relatively small, distinctly shorter than cell VI, its axis consisting of 5-6 cells gradually smaller, each bearing two paired antheridia directed inward except the uppermost, which is sterile. Stalk cell of the perithecium (cell VI) elongate, erect or more frequently curved, gradually broader distally, followed by the almost flattened basal cells of the perithecium. The latter is asymmetrical, with the dorsal (inner) margin distinctly convex and the ventral (outer) slightly concave; the neck is rather abruptly narrower, slightly curved, ending in an undifferentiated tip and blunt apex. Length from foot to perithecial tip 350-390 $\mu \mathrm{m}$; length of the appendage 36-37 $\mu \mathrm{m}$; perithecium 220-245 $\times 52-60 \mu \mathrm{m}$.

Material examined - THAILAND, Chiang Mai prov., Doi Inthanon, Mae Aum, 1640 m, moist evergreen forest, $18^{\circ} 31^{\prime} \mathrm{N}, 98^{\circ} 30^{\prime} \mathrm{E}, 11 \mathrm{Jan} 2014$, Ob legit, at the apex of the abdomen of Neosclerus areolatus Assing (Coleoptera, Staphylinidae), FI WR4040, holotype; same data as the type, WR 4039. A total of five mature and three immature or incomplete thalli have been observed.

Notes - The species of Zeugandromyces described thus far are four Z. australis Thaxt., parasitic on Scopaeus laevis Sharp from Argentina, Z. orientalis (Thaxt.) I. I. Tav., parasitic on Scopaeus nitidulus Motschulski (=subfasciatus Kraatz) from the Philippines, Z. pseudomedonalis (Thaxt.) I. I. Tav., parasitic on Lithocharis thoracica (Casey) from the USA, and Z. stilici (Thaxt.) I. I. Tav., parasitic on Rugilus spp. from Malaysia (type), China, Sri Lanka and Sumatra (Thaxter 1931, Tavares 1985). All these fungi have an elongate appendage, which in Z. orientalis and $Z$. stilici reaches the base of the perithecium and in Z. pseudomedonalis is even longer. Among these four species the most similar to Z. assingii seems to be Z. orientalis, which however has a distinctly acute perithecial apex, a smaller and paler cell II, and the appendage consisting of larger cells bearing longer antheridia in a single row (Try et al. 2017, Fig. 2b).

\section{New Records}

\section{Cantharomyces orientalis Spegazzini}

MycoBank: MB160059

Known distribution - Reported chiefly on Carpelimus spp. (Staphylinidae) from several European countries, from Algeria, and only twice from Asia (Philippines and Turkey) (Rossi 2016).

New record from Thailand - Lamphun prov., Mueang Lamphun distr., harvested rice fields near Umong, 18³7'37’'N, 9903'34'E, 20 Oct \& 1 Nov 2016, W. Rossi, on Carpelimus sp.

Notes - The new record partially fills the large geographical gap in range between the Philippines and Turkey.

\section{Dioicomyces italicus Spegazzini}

MycoBank: MB150123

Known distribution - This fungus is found only on species of the genus Anthelephila (= Formicomus) (Coleoptera, Anthicidae); it was described from Italy and later reported from Bulgaria, Cambodia, Greece, Japan, Philippines, Spain and Turkey sometimes under the synonym Dioicomyces formicomi Thaxt. (Rossi et al. 2018). 
New records from Thailand - Chiang Mai prov., Mae Lai river nr. Ban Pong Din, km 27.6 road no.118 to Chiang Rai, alt. 470 m, 27 Nov 2004, W. Rossi, on various specimens of Anthelephila animata (Pic); Mae Wann river, km 32.3 road no.118 to Chiang Rai, $18^{\circ} 57^{\prime} 37^{\prime \prime} \mathrm{N}$, 99¹4'04'E, alt. 430 m, 21 Oct 2016, W. Rossi, on A. binhensis (Pic); Doi Suthep, artificial lake, 29 Nov 2004, W. Rossi, at the base of the elytra of $A$. consul (LaFerté-Sénectère). Ranong Prov., near Ba Na, 9³4'N, 9842'E, 22-26 Mar 1996, K. Majer, on the abdomen of A. ruficollis Saunders. Chanthaburi distr., Khao Soi Dao, 5-13 May 1998, J. Rolčík, at the apex of the elytra of A. badia (Krekich-Strassoldo).

Notes - Dioicomyces italicus seems quite common in Thailand. The thalli observed on Anthelephila consul are slightly different from those observed on all the other insects of the same genus, its perithecia lacking the conspicuous ridges and the typical reddish tinge. Although not striking, these differences seem constant because were observed also in the thalli found on specimens of $A$. consul from Cambodia (Try et al. 2017).

\section{Eucantharomyces franzinii W. Rossi}

Fig. 10

MycoBank: MB360795

Known distribution - Described from Italy on Zuphium (Parazuphium) chevrolati (Laporte de Castelnau) (Carabidae) (Rossi 1992) end never reported since.

New record from Thailand - Bangkok, 15 Nov 1928, A. Mackie, on Zuphium inconspicuum Schmidt-Goebel.

Notes - This record is the first after the description of the species and also the first for the Asian continent. The thalli from Thailand are only a somewhat stockier than those of the type series.

Ilyomyces cf. dianoi A. Weir

MycoBank: MB413225

Fig. 11

Known distribution - This parasite is known only from the type series, which is made of two thalli found in Indonesia on a femur of Dianous sp. (Coleoptera, Staphylinidae, Steninae) (Weir 1995).

New record from Thailand - Ciang Mai prov., Mae Wann river, km 32.3 road no.118 to Chiang Rai, alt. 430 m, 23 Feb 2017, M. Bernardi \& W. Rossi, on Stenus pustulatus Bernhauer.

Notes - The thalli from Thailand differ from those from Indonesia in having a more symmetrical perithecium with a more tapered tip, in displaying a showy red area around the septum dividing cell III from the free appendage, and the latter producing three antheridia from both its cells 3 and 4 .

Laboulbenia asiatica Thaxter

Figs 12,13

MycoBank: MB162167

Known distribution - Described on "Casnonia" from "Asia" (Thaxter 1908) and reported on Dicranoncus femoralis Chaudoir and Periocypas sp. (Coleoptera, Carabidae) from Malaysia (Sugiyama \& Mochizuka 1979); the parasites on Craspedophorus formosanus Jedlička from Taiwan identified as Laboulbenia asiatica by Sugiyama (1981a) were later described as a new species (L. taiwaniana) by Terada et al. (2008).

New record from Thailand - Lamphun prov., Ban Lam Chan, Tambon Pratu Pa, light trap, $18^{\circ} 37^{\prime} 47^{\prime \prime} \mathrm{N}, 98^{\circ} 59^{\prime} 57^{\prime} \mathrm{E}, 23$ Oct 2016 . W. Rossi, on various parts of the body of Eucolliuris fuscipennis (Chaudoir).

Notes - In the descriptions and drawings given by Thaxter (1908) the differences between Laboulbenia asiatica and $L$. celestialis Thaxt. are not very evident. Thaxter himself wrote about the former: "The species [asiatica] is most nearly related to L. celestialis, of which it may prove to be a luxuriantly developed condition". We have identified the parasites of Eucolliuris fuscipennis as Laboulbenia asiatica for the higher number of branchlets of the appendages, more numerous in the thalli growing on the legs of the host (Fig. 12); this characteristic was described by Thaxter as a 
“... crest-like series of branches, distinguished by black septa ...”. Another feature apparently distinguishing the two species seems to be the length of cell V, which reaches cell III in L. asiatica but not in L. celestialis. The latter feature is not mentioned by Thaxter, but is inferred from his drawings (Thaxter 1908, Plate LXV, Fig. 15). Moreover, the insect reported by Thaxter as the host of L. asiatica is "Casnonia", a name that he utilized for any ground beetle of the tribe Odacanthini, which is the tribe of Eucolliuris fuscipennis.
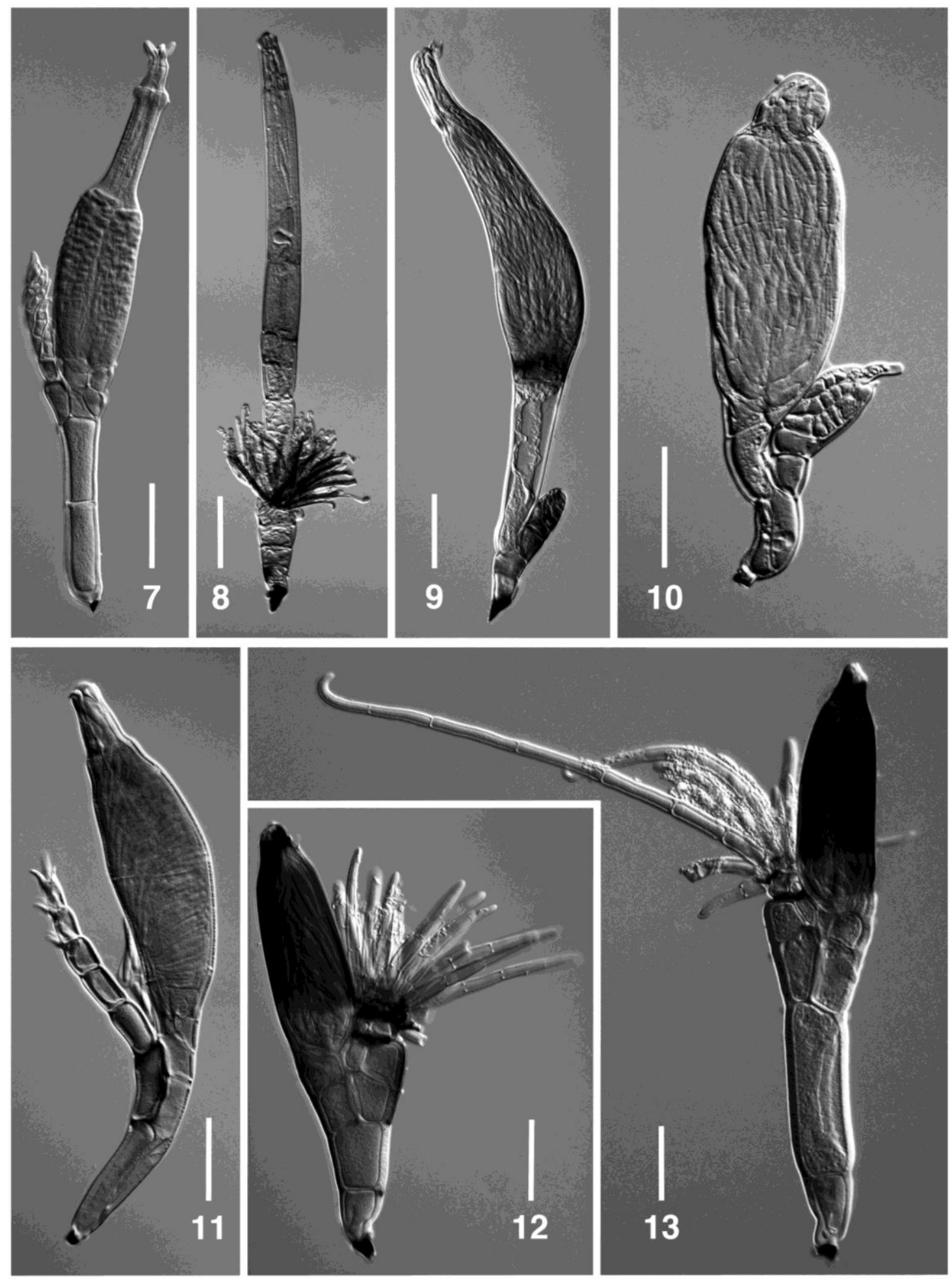

Figures 7-13 - 7 Stigmatomyces coronatus. 8 Teratomyces cylindrocarpus. 9 Zeugandromyces assingii. 10 Eucantharomyces franzinii. 11 Iliomyces cf. dianoi. 12 Laboulbenia asiatica from the legs of the host insect. 13 Laboulbenia asiatica from the elytra of the same insect. Bars $=50 \mu \mathrm{m}$. 
Laboulbenia cristata Thaxter

MycoBank: MB236717

Known distribution - Cosmopolitan and common species occurring on species of the genus Paederus (Staphylinidae) and closely related genera (Majewski 2008).

New record from Thailand - Lamphun prov., Ban Lam Chan, Tambon Pratu Pa, light trap, $18^{\circ} 37^{\prime} 47^{\prime}$ N, 98 $99^{\circ}$ '57’'E, 23 Oct 2016. W. Rossi, all over the body of Paederus fuscipennis Curtis.

Notes - The finding of this species in Thailand is not surprising given its cosmopolitan distribution.

Laboulbenia hottentottae Thaxter

Fig. 14

MycoBank: MB219959

Known distribution - Described from Zanzibar on Lema (L.) hottentotta Lacordaire (Coleoptera, Chrysomelidae, Criocerinae); subsequently reported from various African countries and from China (Balazuc 1988, Shen \& Ye 2006); the record of this parasite from French Guyana on Syphraea sp. (Balazuc 1988) is wrong (personal unpublished observations).

New record from Thailand - Chiang Mai prov., river Mae Lai near Bam Pong Din, km 27.6 road no. 118 to Chiang Rai, 21 Oct 2016, W. Rossi, on various specimens of Lema (L.) saigonensis (Baly) and L. (L.) delauneyi (Baly).

Notes - The fungi found on the two species of Lema from Thailand are quite variable. The thalli occurring on the elytra of the hosts, with slender perithecia and dark but not blackened cells II, III, IV and insertion cell, can be safely identified as Laboulbenia hottentottae although they are shorter than the type, mostly because of a shorter cell II (Fig. 14). The thalli occurring on the abdomen bear more inflated perithecia with the tip curving toward the dorsal side (Fig. 16). The thalli from the tip of the abdomen are very short, with inflated perithecia bearing large lips, and with cell IV bulging upwards (Fig. 15).

The specimens growing on the abdomen are similar to the ones reported from China on Lema sp. by Shen \& Ye (2006, Fig. 120 \& Fig. 6 on Plate I) and identified as Laboulbenia macarthurii Balazuc. This identification is not supported by the comparison of the images given by the Chinese authors with the picture of the type of L. macarturii published by Haelewaters \& Rossi (2015, Fig. $1 \mathrm{E})$.

Because short thalli of the American species Laboulbenia hermeophagae Thaxt. bearing cell IV bulging outwards vaguely resemble L. hottentottae (unpublished observations), the record of the latter from French Guyana on Syphraea sp. (Balazuc 1988) is certainly wrong.

\section{Laboulbenia manubriolata Thaxter}

MycoBank: MB190687

Known distribution - Described from Java (type) and Sri Lanka, subsequently reported from other Asian countries (China, Japan, Taiwan), from a few European countries, and only once from Africa (Sierra Leone) (Majewski 2008); the host insects belong to the genus Perigona (Carabidae).

New record from Thailand - Lamphun prov., Mueang Lamphun distr., harvested rice fields near Umong, 18³7'37’'N, 9903'34'E, 20 Oct \& 1 Nov 2016, W. Rossi, on Perigona nigriceps (Dejean).

Notes - The new finding could be easily anticipated because Thailand is in the middle of the Asian countries where Laboulbenia manubriolata has been already reported.

\section{Laboulbenia partita Thaxter}

MycoBank: MB224914

Known distribution - Described on Nisotra spp. (Chrysomelidae, Alticini) from Cameroon and Madagascar, it was later reported again from Africa (Sierra Leone), from a few Asia countries (Indonesia, Malaysia, Taiwan), and from New Guinea (Rossi 1986).

New records from Thailand - Chiang Mai prov., swamp at $\mathrm{km} 42$ of the road no.118 to Chiang Rai, 27 Nov 2004, W. Rossi, all over the body of Nisotra gemella (Erichson). Chiang Mai 


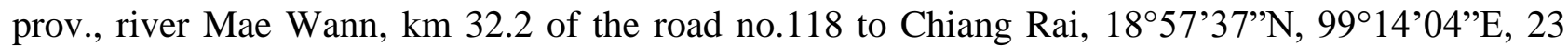
Feb 2017, M. Bernardi \& W. Rossi, on the elytra of three specimens of Chaetocnema (Tlanoma) discreta (Baly).

Notes - The thalli of Laboulbenia partita observed on Chaetocnema are shorter than those parasitic on Nisotra, but otherwise not distinguished.

While the finding of L. partita on Nisotra gemella is not surprising given its presence on the same host in the nearby countries, the finding of this parasite on Chaetocnema discreta is unexpected. Actually, the species of Laboulbenia reported thus far on Chaetocnema spp. from America and Europe are very different, with appendages lacking any sterile branch and with undivided cells III, IV and V.

\section{Laboulbenia polymorpha K. Sugiyama}

MycoBank: MB316147

Known distribution - Described on Ophionea indica (Thumberg) from Japan and Taiwan, subsequently reported from China on the same host insect and on Desera geniculata (Klug) (Carabidae) (Shen \& Ye 2006).

New record from Thailand - Lamphun prov., Ban Lam Chan, Tambon Pratu Pa, light trap, $18^{\circ} 37^{\prime} 47^{\prime} \mathrm{N}, 98^{\circ} 59^{\prime} 57^{\prime} \mathrm{E}, 23$ Oct 2016 . W. Rossi, on elytra and pronotum of Ophionea indica (Thumberg).

Notes - In the original description (Sugiyama 1978b), three different "forms" were reported. The type series was re-examined by Terada (2004) who carefully re-described these three morphotypes and named them with the letters $\mathrm{C}, \mathrm{D}$ and $\mathrm{E}$. The thalli found on the elytra and the pronotum of $O$. indica in Thailand perfectly match the morphotype named $\mathrm{C}$-form by Terada (2004, Figs 1-6). On the legs of the same host were found several thalli broadly club-shaped, which cannot be assigned to any of the three morphotypes of Laboulbenia polymorpha.

\section{Laboulbenia sciakyi W. Rossi \& Cesari}

MycoBank MB110745

Known distribution - Described on Planetes elegans Nietner (Carabidae), this species is only known from Sri Lanka (Rossi \& Cesari Rossi 1982).

New record from Thailand - $40 \mathrm{Km}$ N Phutchabun, 1986, Thielen, on pronotum and elytra of Planetes ruficollis (Nietner)

Notes - The parasites from Thailand are identical with those described from Sri Lanka. In a few thalli the outer branch of the appendage is dichotomously divided twice, but the majority have the same divided only once as in the type series.

Monandromyces neoalardi R. K. Benjamin

Fig. 17

MycoBank: MB459859

Known distribution - Only known from the type series, which was found in Malaysia on Neoalardus typicus (Distant) (Heteroptera, Veliidae) (Benjamin 1999).

New record from Thailand - Chiang Mai prov., River Mae Wann, km 32.3 road no.118, 21 Oct 2016, W. Rossi, on various specimens of N. typicus.

Notes - The thalli from Thailand are identical with the thalli described from the nearby Malaysia on the same host-insect. The species is unmistakable for its very peculiar perithecial apex.

Monoicomyces luxurians W. Rossi \& Santamaria

Fig. 18

MycoBank: MB360568

Known distribution - Described on Drusilla sp. (Staphylinidae) from the Democratic Republic of the Congo (formerly Zaire) (Rossi \& Santamaria 1992) this parasite was never recorded again.

New record from Thailand - Kanchanaburi prov., Ban Sai Yok, Kwai River, Mar 1984, G. de Rougemont, on Drusilla khamhengi Pace. 
Notes - First record after its description and also first record for the Asian continent. The thalli from Thailand fit the original description quite well.

Monoicomyces cf. leptochiri Thaxter

Fig. 19

MycoBank: MB189080

Known distribution - This species has been recorded only in the Asian continent: described from Indonesia and the Philippines, was later reported from Japan and Taiwan (Sugiyama 1978a); the hosts are Staphylinidae Leptochirini.

New record from Thailand - Chiang Mai prov., Doi Suthep, nature trail Phalad, 29 Nov 2004, W. Rossi, on the abdomen of Priochirus sp.

Notes - The thalli from Thailand are somewhat intermediate between Monoicomyces leptochiri and M. osorianus Thaxt., described from Cameroon on Neosorius opaculus (Eppelsheim) (Thaxter 1931). They have a sessile perithecium and dark brown suffusions at the septa between the cells of the axis as in the former species, but their antheridial appendages bear distally up to eight hyaline branchlets as in the latter.

Neohaplomyces cf. medonalis R. K. Benjamin

MycoBank: MB301812

Known distribution - The records of this species are quite scattered: it has been described on Medon sp. (Staphylinidae) from the U. S. A. and subsequently reported from Greece, Madagascar, Panama, Spain and Turkey on Medon spp., Thinocharis sp., and unidentified Medonina (Haelewaters et al. 2017).

New record from Thailand - Ciang Rai prov., district Wiang Pa Pao, Huay Nam Guen, about 1250 m, 1907'40”N, 99¹9'42'E, 22-23 Feb 2017, M. Bernardi \& W. Rossi, on various ventral parts of an undetermined genus and species of the Medonina.

Notes - The record from Thailand is the second for Asia and extends considerably the known distribution of the parasite.

\section{Peyritschiella hybrida (Thaxter) I. I. Tavares}

MycoBank: MB105644

Known distribution - Widely distributed in Asia on various species of Philonthus and Spatulonthus (Staphylinidae); also reported in North and Central America and in a few European countries (Try et al. 2017).

New record from Thailand - Lamphun prov., Ban San Ka Yom, light trap, 30 Oct 2016, W. Rossi, all over the body of two specimens of Philonthus variipennis Kraatz and one Philonthus sp.

Notes - The very many thalli observed on the three host-insects reported above are very variable. The perithecia of the fungi from the ventral part of the head are not auriculate and are very similar to the thallus depicted in Thaxter 1908, Plate XXXI, Fig. 15. The thalli from the abdomen bear auriculate perithecia, but those from the dorsal surface have, on average, longer fork-like, blackish projections. On the tarsi of the same host insects were also present several thalli of Peyritschiella subinaequilatera (Speg.) Speg. (see below).

\section{Peyritschiella nigrescens Thaxter}

MycoBank: MB181067

Known distribution - This species was described from the U.S.A and later recorded from a few European countries, from Taiwan and from China; the host insects were all reported as species of the genus Philonthus (Staphylinidae) (Shen \& Ye 2006).

New record from Thailand - Lamphun prov., Mueang Lamphun distr., harvested rice fields near Umong, $18^{\circ} 37^{\prime} 37^{\prime}$ 'N, 99 03 '43'E, 13 \& 15 Feb 2017, M. Bernardi \& W. Rossi, at the apex of the abdomen of Neobisnius praelongus (Gemminger et Harold).

Notes - The thalli from Thailand are all asymmetrical, with a single antheridium and a single perithecium asymmetrically placed. 

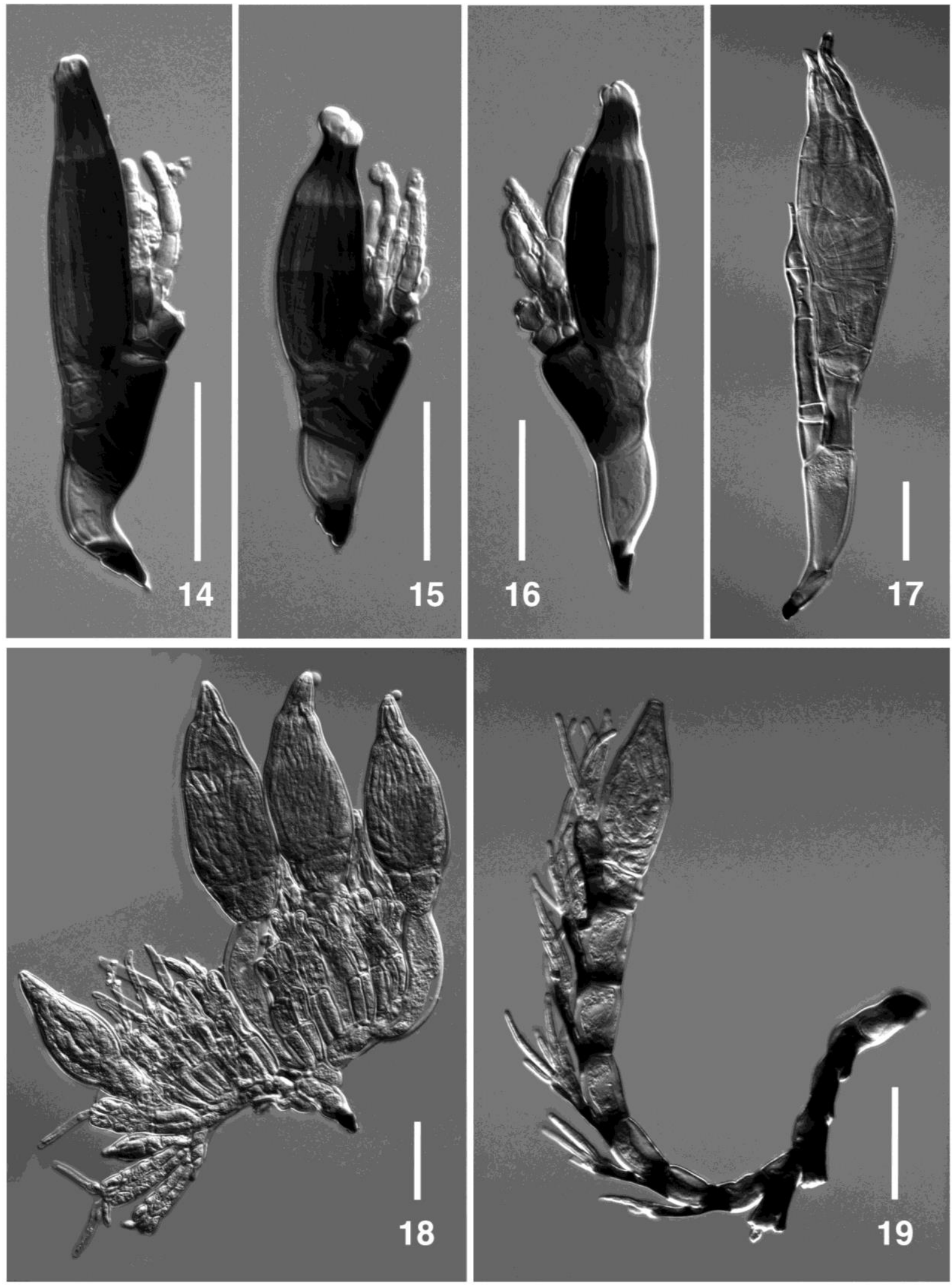

Figures 14-19 - 14 Laboulbenia hottentottae from the elytra of Lema delauneyi. 15 Laboulbenia sp. from the abdomen of Lema delauneyi. 16 Laboulbenia sp. from the apex of the abdomen of Lema delauneyi. 17 Monandromyces neoalardi. 18 Monoicomyces luxurians. 19 M. cf. leptochiri. Bars $=50 \mu \mathrm{m}$.

Peyritschiella subinaequilatera (Spegazzini) Spegazzini Fig. 20 MycoBank: MB188512 
Known distribution - This fungus was described from Ethiopia and later recorded from Argentina, Spain and Italy [from the latter country under the synonym P. anisopleura (Speg.) Speg.] on various species of Philonthus (Santamaria 1999).

New record from Thailand - Lamphun prov., Ban San Ka Yom, light trap, 30 Oct 2016, W. Rossi, on the tarsi of Philonthus variipennis and Philonthus sp.

Notes - As written above, Peyritschiella subinaequilatera was found on the tarsi of the same insects bearing $P$. hybrida on other parts of the body. Thaxter (1931) suggested that $P$. subinaequilatera could be a "form" of other species, growing on the distal portion of the tarsi of the insects, but Santamaria (1999) maintained it as a distinct species because of the presence of thalli displaying the same morphological features also when growing on other parts of the hosts.

\section{Rickia ancylopi Thaxter}

MycoBank: MB183965

Known distribution - This species was described on Ancylopus bisignatus Gerstaecker (Coleoptera, Endomychidae) from Cameroon, but all the following records (on Ancylopus spp.) are from Asia: China, India, Korea, Japan, Malaysia and Taiwan (Shen \& Ye 2006).

New record from Thailand - Ciang Mai prov., near Mae Rim, Huay Tung Tao reservoir, 18 $51^{\prime} 49^{\prime}$ 'N, 98 $56^{\prime} 24^{\prime \prime} \mathrm{E}, 24$ Oct 2016, W. Rossi, on a few specimens of Ancylopus pictus asiaticus Strohecker.

Notes - The finding of Rickia ancylopi in Thailand is far from being surprising given its large distribution area and the previous record from the nearby Malaysia.

Rickia berlesiana (Baccarini) Paoli

Fig. 21

MycoBank: MB183879

Known distribution - Widely distributed in South-East Asia and in Oceania on various families of mites (mainly Fedrizziidae, but also Cillibiidae, Celaenopsidae, Macrochelidae, Uropodidae) and on unidentified Passalidae (Coleoptera). The complete list of records is: ASIA India (Samšiňáková 1960); Indonesia (Thaxter 1915); Malaysia (Sugiyama \& Mochizuka 1979); Sri Lanka (Thaxter 1926). OCEANIA - Australia (Baccarini 1904: type, Thaxter 1926, Seeman \& Nahrung 2000), Fiji and Solomon Islands (Thaxter 1926).

New record from Thailand - Ciang Rai prov., district Wiang Pa Pao, Huay Nam Guen, about 1250 m, 1907'40'N, 99¹9'42'E, light trap, 26-28 Oct 2016, W. Rossi, on a few Neofedrizzia sp. (Fedrizziidae) associated with a female specimen of Aceraius helferi Kuwert (Passalidae). Ibidem, 25 May 2017, F. Ferrero, on several specimens of Neofedrizzia janae Seeman.

Notes - The new findings make it possible to point out the peculiar features of the bicellular ascospores of Rickia berlesiana. The tip of the shorter cell is nipple-shaped, while the distal portion of the longer cell, on the opposite side, is club-shaped (Fig. 21). In the large majority of the Laboulbeniales both the ends of the ascospores are sharply pointed. It is also worth mentioning that an immature thallus of Rickia uncinata was observed growing on the perithecium of a thallus of $R$. berlesiana, the two thalli being of almost the same length (Fig. 21). The former species was very abundant on the bristles of Aceraius helferi (see further on), the host of the host of Rickia berlesiana. Sometimes very immature thalli of Laboulbeniales are found on older thalli of the same species (Thaxter 1926, Plate XIII, Fig. 240, Rossi 1992, Fig. 10), but to our knowledge this is the first record of one of these fungi growing on the thallus of a different species.

\section{Rickia coleopterophagi Paoli}

MycoBank: MB191144

Known distribution - Described on the mite Coleopterophagus procerus Berlese (Canestriniidae) associated with Oryctes rhinoceros (L.) (Scarabaeidae) from India (Paoli 1911), subsequently reported in Africa on Passalacarus sp. (Diplogyniidae) associated with Oryctes owariensis Palisot from Guinea (Balazuc 1973) and on Cingulacarus sp. (sub Lobogynioides sp.) (Diplogyniidae) associated with Oryctes owariensis from Sierra Leone (Rossi 1994). 
New record from Thailand - Lamphun prov., near Ban Chetawan, 1 Nov 2016, W. Rossi, on Diplogynium oryctae Vishnupriya et Mohanasundaram (Diplogyniidae) associated with Oryctes rhinoceros collected by light trap.

Notes - The single, immature thallus from Thailand is almost identical with the immature thallus depicted by Paoli in the protologue (Paoli 1911, plate XII, Fig. 3).

The host of Rickia coleopterophagi from Sierra Leone was reported as "Lobogynioides sp.", but was later identified as Cingulacarus sp. by Owen Seeman (Australia).

Rickia flagellifera Thaxter

Fig. 22

MycoBank: MB186996

Known distribution - This parasite has been recorded only once, on Leptaulax dentatus (Fabricius) (Passalidae) from the Philippines (Thaxter 1926).

New record from Thailand - Doi Inthanon near Khun Wang, under the bark of a fallen tree, 28 Nov 2004, W. Rossi, on the bristles at the apex of the abdomen of L. dentatus.

Notes - Among the thalli from Thailand, most of which have a single perithecium (Fig. 22), there are some with up to four perithecia.

\section{Rickia leptaulacis Thaxter}

MycoBank: MB269270

Known distribution - Described on Leptaulax dentatus from the Philippines as the previous species (Thaxter 1926) and more recently reported from Northern Australia not only on other Passalidae, but also on the mites Fedrizzia grossipes Canestrini (Fedrizziidae) and Meghistanus spp. (Megistanidae) (Seeman \& Nahrung 2000).

New record from Thailand - Ciang Rai prov., district Wiang Pa Pao, Huay Nam Guen, about $1250 \mathrm{~m}, 1^{\circ} 07^{\prime} 40^{\prime} \mathrm{N}, 9^{\circ} 19^{\prime} 42^{\prime}$ 'E, under the bark of a fallen tree, 22-23 Feb 2017, M. Bernardi \& W. Rossi, on Fedrizzia gilloglyi Seeman associated with Leptaulax dentatus.

Notes - The new record confirms the presence of this parasite on both Passalidae and associated mites.

Rickia uncinata Thaxter

Fig. 23

MycoBank: MB188720

Known distribution - The original description is based on thalli found "on the bristles of a large Passalidae from Java" and on the legs of a mite inhabiting Pelopides monticulosus (Smith) (Passalidae) from Sumatra (Thaxter 1926); it was subsequently reported only from Malaysia on "a large passalid insect” (Sugiyama \& Mochizuka 1979).

New records from Thailand - Ciang Rai prov., district Wiang Pa Pao, Huay Nam Guen, about $1250 \mathrm{~m}, 1^{\circ} 07^{\prime} 40^{\prime \prime} \mathrm{N}, 9^{\circ} 19^{\prime} 42^{\prime \prime} \mathrm{E}$, light trap, 26-28 Oct 2016, W. Rossi, on the bristles of Aceraius helferi Kuwert (Passalidae). Ibidem, 25 May 2017, F. Ferrero, on the bristles of A. helferi and on several large mites (Meghistanus sp., Megisthanidae) associated with the same beetle.

Notes - Aceraius helferi is a "large" Passalidae almost $4 \mathrm{~cm}$ long and has a distribution area ranging from India to China. It is therefore possible that some of the previous unidentified hosts of Rickia uncinata were A. helferi.

Recent findings have shown that the presence of the same species of the Laboulbeniales on an insect and on the mites associated with the same insect is not so rare as suggested by the scarcity of previous reports (Seeman \& Nahrung 2000, Rossi et al. 2016).

Stigmatomyces dubius Thaxter

Fig. 24

MycoBank: MB192098

Known distribution - Known only from the type series, described upon parasites found on an unidentified fly from the Bismarck Archipelago (Papua-New Guinea) (Thaxter 1901). 
New record from Thailand - Chiang Mai prov., Mae Wann river, km 32.3 road no.118 to Chiang Rai, 430 m, 27 Nov 2004, W. Rossi, on the left hind tibia Ochthera guangdongensis Zhang \& Yang (Ephydridae).

Notes - First record for the Asian continent. The thalli from Thailand are stockier, mostly because of a shorter receptacle: which is not unusual in parasites growing on the legs of the host insects. However, they have the characteristic "hamate" longer lip overlapping the others and the long appendage consisting of 8-9 cells exceeding in height the perithecial venter.

The host of $S$. dubius was described as "a fly with monstrously developed anterior legs resembling those of Ochtheria mantis" collected by S. Dahl at "Ralum, New Pomerania" (now New Britain, in the Bismarck Archipelago) and preserved in the "Museum of Natural History" of Berlin (Thaxter 1901). Because several years ago the first author received from the Museum für Naturkunde (Berlin) a specimen of Ochthera brevitibialis de Meijere bearing thalli of $S$. dubius, labeled "Ralum, S. Dahl, 2/6.1896", it could well be that the unidentified fly seen by Thaxter belongs to this same species.

\section{Stigmatomyces excavatus Thaxter}

MycoBank: MB187596

Fig. 25

Known distribution - Described on Notiphila sp. (Ephydridae) from Cameroon (Thaxter 1918) and never recorded since.

New record from Thailand - Chiang Mai prov., swamp km 42 road no.118 to Chiang Rai, 27 Nov 2004, W. Rossi, on various parts of a male specimen of Notiphila phaea Hendel.

Notes - The thalli from Thailand are short but have, as in the type series, a long and slender appendage with the axis consisting of 7 cells and its stalk-cell extending upward forming a rounded bulge.

The finding from Thailand is the first for the Asian continent. However, in the WR collection there are two unpublished records from the Middle East which partially fill the huge geographical gap between the Indochinese Peninsula and Cameroon. These records are as follows: ISRAEL, Menahamiya, 32.67N, 35. 57E, 27 Oct 2011, N. Vikhrev, on the tergites of a female specimen of Notiphila dorsata Stenhammar. JORDAN, Azraq Reserve, 8 Oct 2000, W. Rossi, on N. irrorata Cogan.

Stigmatomyces tortilis Thaxter, Proceedings of the American Academy of Arts and Sciences 53(9): 721, 1918 [MB187596]

Fig. 26

= Stigmatomyces subcircinalis Thaxter, Memoirs of the American Academy of Arts and Sciences 16(1): 118, 1931 [MB279140] syn. nov.

Known distribution - This parasite was described on Lispe sp. (Diptera, Muscidae) from Cameroon (Thaxter 1918) and later re-described as S. subcircinalis on Lispe sp. from Indonesia (Thaxter 1931).

New record from Thailand - Saraburi prov., Muak Lek Falls, 3 Sept 1981, W. Rossi, on Lispe leucospila Wiedeman; Chomburi, SaiKaew, 16.I.2008, N. Vikhrev, on various specimens of $L$. leucospila.

Notes - It suffices to draw near to each other figures no.13 of plate XXVIII (Stigmatomyces tortilis) and no.16 of plate XXIX (S. subcircinalis) in Thaxter's monograph of 1931 to make it evident that these two figures show the same species. Any doubt will be eliminated by reading the detailed descriptions on page 118 of the same publication.

\section{Tettigomyces acuminatus Thaxter}

MycoBank: MB239061

Known distribution - Described from Java, subsequently reported from the Philippines, Kenya, China and, more recently, from Sierra Leone (Rossi \& Leonardi 2018); the host insects were reported as Gryllotalpa africana Palisot de Beauvois (Orthoptera, Gryllotalpidae). 

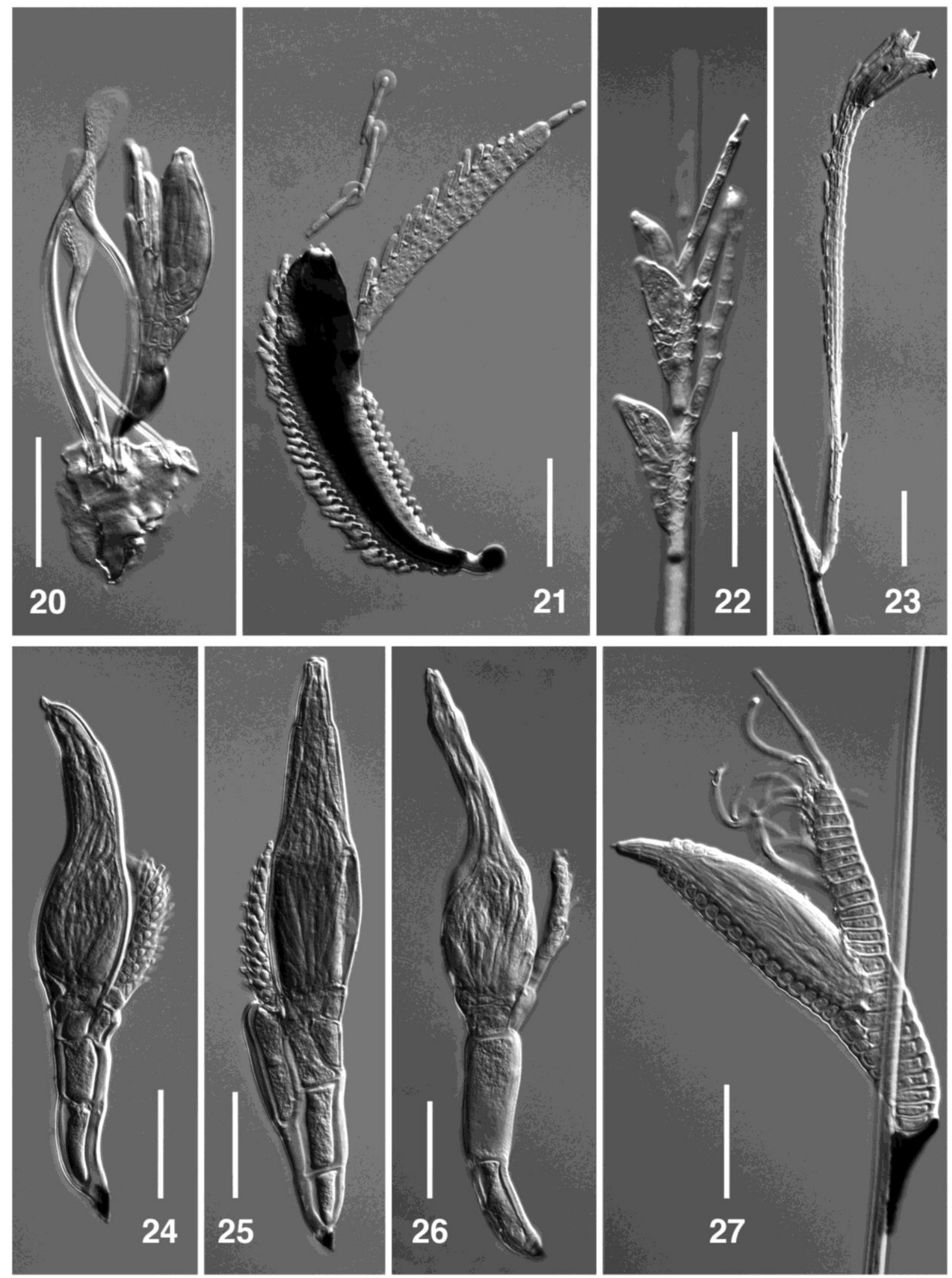

Figures 20-27 - 20 Peyritschiella subinaequilatera. 21 Rickia berlesiana. 22 R. flagellifera. 23 R. uncinata. 24 Stigmatomyces dubius. 25 S. excavatus. 26 S. tortilis. 27 Tettigomyces chaetophilus.

New record from Thailand - Lamphun prov., Mueang Lamphun distr., harvested rice fields near Umong, 18³7’37'N, 9903’34'E, 15 Feb 2017, M. Bernardi \& W. Rossi, on abdominal appendages of Gryllotalpa sp. 
Notes - The name Gryllotalpa africana has been used for a long time also for the Asian mole-crickets, but more recent studies have shown that this species is not found in Asia, where other 26 species of Gryllotalpa were recenltly recorded (Tan 2016).

Tettigomyces chaetophilus Thaxter

Fig. 27

MycoBank: MB239230

Known distribution - Like the previous species, this fungus was described from Java, but later was reported only from China (Thaxter 1926, Shen \& Ye 2006); the host insects of both findings were reported as "Gryllotalpa africana".

New record from Thailand - Lamphun prov., Mueang Lamphun distr., harvested rice fields near Umong, 18³7’37’N, 9903'34'E, 15 Feb 2017, M. Bernardi \& W. Rossi, on the bristles of the abdominal appendages of Gryllotalpa sp.

Notes - See the "Notes" of the previous species.

\section{Discussion}

Laboulbeniales from the Indochinese peninsula are poorly known and it is therefore impossible to infer from the known data any conclusion about the biodiversity of the Laboulbeniales of the area. Also, the numbers of these parasites recorded from the single countries are very low and uncertainties exist because of doubtless identifications and synonyms. Taking this into account, the figures are as follows: in the peninsular Malaysia were reported thus far 55 species, only 15 of which are also reported from Thailand; the comparison with Burma is 5 species in common among the 20 reported; in Cambodia were recently recorded 16 species, 8 of which are also present in Thailand; no comparison is possible with Laos because not a single species has been recorded thus far from this country.

\section{Acknowledgements}

The authors wish to thank the numerous entomologists who identified or supplied insects bearing Laboulbeniales: F. Angelini, Italy (Leiodidae); V. Assing, Germany (Staphylinidae); M. Baehr, Germany (Carabidae); M. Biondi, Italy (Chrysomelidae); S. Boucher, France (Passalidae); F. Cianferoni, Italy (Veliidae); A. Haustov, Russia (mites); Z. Kejval, Czech Rep. (Anthicidae); M. Krivosheina, Russia (Ephydridae); G. Makranczy, Hungary (Staphylinidae); V. Puthz, Germany (Staphylinidae); S. Rocchi, Italy (Dytiscidae, Hydrophilidae); O. Seeman, Australia (mites); F. W. Shockley, U. S. A. (Endomychidae); N. Vikhrev, Russia (Muscidae); T. Zatwarnicki, Poland (Ephydridae). They are also grateful to S. Santamaria (Spain) for the pictures with DIC optics and to K. Terada (Japan) for helpful suggestions.

Special thanks are due to Franco Ferrero for his help during the journeys of 2016 and 2017, and to Hans Banziger for his help during the journey of 2004.

\section{References}

Baccarini P. 1904 - Noterelle micologiche. Nuovo Giornale Botanico Italiano, nuova serie. Memorie 11, 416-422. Tav. 4.

Balazuc J. 1973 - Recherches sur les Laboulbéniomycètes, I. Trois espèces nouvelles et une mal connue. Revue de Mycologie 37, 253-262.

Balazuc J. 1988 - Laboulbeniales (Ascomycetes) parasitic on Chrysomelidae. In: Jolivet P, Petitpierre E, Hsiao TH (eds) Biology of Chrysomelidae. Kluwer Academic Publishers, Dordrecht, 389-398.

Benjamin RK. 1999 - Laboulbeniales on semiaquatic Heteroptera. VIII. Monandromyces, a new genus based on Autophagomyces microveliae (Laboulbeniales). Aliso 18, 71-91.

Bernardi M, Barragán A, Rossi W. 2014 - New records of Laboulbeniales (Fungi: Ascomycota) from Ecuador and other countries. Webbia 69, 281-289.

https://doi.org/10.1080/00837792.2014.953369 
Blackwell M. 1980 - Incidence, host specificity, distribution, and morphological variation in Arthrorhynchus nycteribiae and A. eucampsipodae (Laboulbeniomycetes). Mycologia 72, 143-158.

Haelewaters D, Rossi W. 2015 - Three new species of Laboulbenia from Roland Thaxter's backlog of slides and a brief review of Laboulbeniales associated with Chrysomelidae. Mycologia 107:142-148. http://dx.doi.org/10.3852/14-022

Haelewaters D, Verhaeghen SJC, Rios GTA, Bernal Vega JA, Villareal SRV. 2017 - New and interesting Laboulbeniales from Panama and neighboring areas. Nova Hedwigia (published online). https://doi.org/10.1127/nova_hedwigia/2017/0410

Majewski T. 2008 - Atlas of the Geographical Distribution of Fungi in Poland. 4. Laboulbeniales. W. Szafer Institute of Botany, Polish Academy of Sciences, Krakow.

Paoli G. 1911 - Nuovi Laboulbeniomiceti parassiti di Acari. Redia 7, 283-295 (published again in Malpighia 24, 329-340, 1911).

Rossi W. 1986 - Su alcune specie di Laboulbenia nuove o interessanti della Sierra Leone. Accademia Nazionale dei Lincei, Quaderno 260, 77-96.

Rossi W. 1987 - New Laboulbeniales (Ascomycetes) parasitic on Diptera. Nova Hedwigia 44, 461-464.

Rossi W. 1988 - New or interesting Laboulbeniales (Ascomycetes) parasitic on Diptera. Webbia 42, 171-178.

Rossi W. 1992 - Nuove o interessanti Laboulbeniali (Ascomycetes) parassite di Carabidi italiani (Insecta, Coleoptera). Webbia 46, 277-290.

Rossi W. 1994 - A new contribution to the knowledge of the Laboulbeniales (Ascomycetes) from Sierra Leone. Accademia Nazionale dei Lincei, Quaderno 267, 5-17.

Rossi W. 2010 - New Laboulbeniales (Ascomycota) parasitic on Staphylinidae from Ecuador. Mycological Progress 9, 407-415. https://doi.org/10.1007/s11557-009-0650-0

Rossi W. 2016 - Contribution to the knowledge of the Laboulbeniales (Ascomycota) from Turkey. Webbia 71, 265-276. https://doi.org/10.1080/00837792.2016.1222668

Rossi W, Bernardi M, Torres JA. 2015 - New species of Dimeromyces from Ecuador. Mycological Progress 14, 5. https://doi.org/10.1007/s11557-015-1026-2

Rossi W, Bernardi M, Torres JA. 2016 - New species of Laboulbenia parasitic on leaf beetles. Mycological Progress 15, 4. https://doi.org/10.1007/s11557-015-1146-8

Rossi W, Cesari Rossi MG. 1977 - Deux Laboubeniales nouvelles, parasites de Zuphiini (Coleoptera, Carabidae). Canadian Journal of Botany 55, 1575-1580.

Rossi W, Cesari Rossi MG. 1982 - Quelques espèce nouvelle de Laboubéniales (Ascomycetes), parasites de Carabiques. Canadian Journal of Botany 60, 306-309.

Rossi W, Guéorguiev B, Georgiev G, Stoianova D. 2018 - Laboulbeniales (Ascomycota) from Bulgaria and other countries. Plant Biosystems.

https://doi.org/10.1080/11263504.2018.1454531

Rossi W, Leonardi M. 2013 - New species of Stigmatomyces (Laboulbeniomycetes) from Sierra Leone. Plant Biosystems 147, 79-83. https://doi.org/10.1080/11263504.2012.695297 (online 2012)

Rossi W, Leonardi M. 2018 - New species and new records of Laboulbeniales (Ascomycota) from Sierra Leone. Phytotaxa 358, 91-116. https://doi.org/10.11646/phytotaxa.358.2.1

Rossi W, Santamaría S. 1992 - New Laboulbeniales (Ascomycetes) from Zaire. Nova Hedwigia $55,519-525$.

Rossi W, Santamaria S. 2015 - New species of Aporomyces. Turkish Journal of Botany 39, 354358. https://doi.org/10.3906/bot-1404-104

Rossi W, Santamaría S, Andrade R. 2013 - Notes on the Laboulbeniales (Ascomycota) parasitic on Diptera from Portugal and other countries. Plant Biosystems 147, 730-742.

https://doi.org/10.1080/11263504.2012.753132

Samšiňáková A. 1960 - Nový nález Rickia berlesiana (Bacc.) Paoli (Laboulbeniales). Česká Mykologie. 14, 49-52. 
Santamaria S. 1999 - New or interesting Iberian Laboulbeniales (Fungi, Ascomycota). Nova Hedwigia 68, 351-364.

Santamaria S. 2001 - The genus Chitonomyces (Laboulbeniales, Ascomycota) in Spain. Nova Hedwigia 73, 339-365.

Santamaria S. 2004 - Two new genera of Laboulbeniales allied to Zodiomyces. Mycologia 96, 761772.

Santamaria S, Balazuc J, Tavares II. 1991 - Distribution of the European Laboulbeniales (Fungi, Ascomycotina). An annotated list of species. Trebals de l'Institut Botànic de Barcelona 14, 5123.

Santamaria S, Rossi W. 1999 - New or interesting Laboulbeniales from the Mediterranean region. Plant Biosystems 153, 163-171.

Seeman OD, Nahrung HF. 2000 - Mites as fungal vectors? The ectoparasitic fungi of mites and their arthropod associated in Queensland. Australasian Mycologist 19, 3-9.

Shen YH, Ye DH. 2006 - Laboulbeniales. Flora Fungorum Sinicorum 28, 1-294.

Sugiyama K. 1978a - The Laboulbeniomycetes of eastern Asia (2) On eight species from Japan and Formosa including two new species of Rickia. Journal of Japanese Botany 53, 154-160.

Sugiyama K. 1978b - The Laboulbeniomycetes of Eastern Asia. (3) On nine species including two new species. Journal of Japanese Botany 53, 281-288.

Sugiyama K. 1981a - Notes on Laboulbeniomycetes of Formosa III. Transactions of the Mycological Society of Japan 22, 311-319.

Sugiyama K. 1981b - On two new species of the genus Eucantharomyces (Laboulbeniomycetes, Ascomycotina). Transactions of the Mycological Society of Japan 22, 413-418.

Sugiyama K, Mochizuka H. 1979 - The Laboulbeniomycetes (Ascomycotina) of Peninsular Malaysia. Transactions of the Mycological Society of Japan 20, 339-355.

Sugiyama K, Phanichapol D. 1984 - Laboulbeniomycetes (Ascomycotina) in Thailand, I. Natural History Bulletin of the Siam Society 32, 47-88.

Tan MK. 2016 - Annotated checklist and key to species of Gryllotalpa (Orthoptera: Gryllotalpidae) from Oriental region. Zootaxa. 4132, 77-86. https://doi.org/10.11646/zootaxa4132.1.6

Tavares II. 1985 - Laboulbeniales (Fungi, Ascomycetes). Mycological Memoirs 9, 1-627.

Terada K. 2004 - Morphological variation in Laboulbenia polymorpha (Laboulbeniales). Mycoscience 45, 324-332. https://doi.org/10.1007/s10267-004-0190-z

Terada K, Hsu MH, Wu WJ. 2008 - A new species of the genus Laboulbenia (Laboulbeniales) on Craspedophorus formosanus (Coleoptera, Carabidae) from Taiwan, with a note on Laboulbenia asiatica. Aliso 26, 23-27. http://scholarship.claremont.edu/aliso

Thaxter R. 1901 - Preliminary Diagnoses of New Species of Laboulbeniales. III. Proceedings of the American Academy of Arts and Sciences 36, 397-414. http://dx.doi.org/10.2307/20021044

Thaxter R. 1908 - Contribution toward a monograph of the Laboulbeniaceae. Part II. Memoirs of the American Academy of Arts and Sciences 13, 217-469.

Thaxter R. 1915 - New Indo-Malayan Laboulbeniales. Proceedings of the American Academy of Arts and Sciences 51, 1-51. http://dx.doi.org/10.2307/20025560

Thaxter R. 1918 - Extra American Dipterophilous Laboulbeniales. Proceedings of the American Academy of Arts and Sciences 53, 697-749. http://dx.doi.org/10.2307/25130007

Thaxter R. 1926 - Contribution towards a monograph of the Laboulbeniaceae. Part IV. Memoirs of the American Academy of Arts and Sciences 15, 427-580.

Thaxter R. 1931 - Contribution towards a monograph of the Laboulbeniaceae. Part V. Memoirs of the American Academy of Arts and Sciences 16, 1-435.

Try Y, Kong V, Rossi W. 2017 - First records of Laboulbeniales (Ascomycota) from Cambodia. Webbia 72, 287-293. https://doi.org/10.1080/00837792.2017.1359476

Weir A. 1995 - Two new species of Ilyomyces. Mycological Research 99, 789-792. 